Article

\title{
Sub-Lethal Effects of Partially Purified Protein Extracted from Beauveria bassiana (Balsamo) and Its Presumptive Role in Tomato (Lycopersicon esculentum L.) Defense against Whitefly (Bemisia tabaci Genn.)
}

\author{
Azhar Uddin Keerio ${ }^{1, *,+}$, Talha Nazir 1,+(D), Tauqir Anwar ${ }^{2}$, Muhammad Zeeshan Majeed ${ }^{3}$, \\ Yusuf Ali Abdulle ${ }^{1}$, Ghulam Hussain Jatoi ${ }^{1,4} \mathbb{D}^{\text {, Muswar Ali Gadhi }}{ }^{1}$ and Dewen Qiu ${ }^{1, *}$ \\ 1 State Key Laboratory for Biology of Plant Diseases and Insect Pests, Institute of Plant Protection, \\ Chinese Academy of Agricultural Sciences, Beijing 100081, China; talha23december@gmail.com (T.N.); \\ idaajaa236@gmail.com (Y.A.A.); jatoighulamhussain@hotmail.com (G.H.J.); \\ muswarali860@gmail.com (M.A.G.) \\ 2 Pest Warning \& Quality Control of Pesticides, Punjab Agriculture Department, Government of the Punjab, \\ Sillanwali 40010, Pakistan; tauqeer26@gmail.com \\ 3 Department of Entomology, University of Sargodha, Sargodha 40100, Pakistan; zeeshan.majeed@uos.edu.pk \\ 4 Department of Plant Pathology, Sindh Agriculture University, Tandojam 70060, Pakistan \\ * Correspondence: azharkeeryo@gmail.com (A.U.K.); qiudewen@caas.cn (D.Q.); Tel.: +86-13520642805 (D.Q.) \\ + These authors contributed equally to this work.
}

Received: 17 June 2020; Accepted: 14 August 2020; Published: 27 August 2020

check for updates

Simple Summary: Apart from their direct entomopathogenicity, many entomopathogenic fungi synthesize protein molecules that can trigger plant defense mechanisms against herbivore insect pests. This laboratory study determined the sub-lethal effects of a partially purified protein derived from Beauveria bassiana against whitefly Bemisia tabaci on tomato plants along with the subsequent gene expression analyses of key gens potentially linked to jasmonic acid (JA) and salicylic acid (SA) associated plant defense pathways. The exogenous foliar application of B. bassiana-derived protein significantly reduced the whitefly survival and fecundity parameters concomitantly with an up-regulation of all the plant defense associated genes, particularly of SA pathway genes. These findings demonstrate the putative role of this partially purified entomopathogenic fungal protein and suggest its further purification and characterization for using in future microbial pest control strategies against whiteflies and other sap-feeding insect pests.

Abstract: Plants rely on various physiological and molecular defense mechanisms against biotic stresses such as herbivore insects. Many entomopathogenic fungi synthesize protein molecules that can trigger these plant defenses. This laboratory study characterized the bioactivity of a partially purified protein derived from Beauveria bassiana (ARSEF 2860) against whitefly, Bemisia tabaci (Hemiptera: Aleyrodidae), which is an economically important pest of agricultural and horticultural crops worldwide. Different concentrations (i.e., $0.021,0.042$ and $0.063 \mu \mathrm{M}$ ) of fungal protein were bioassayed to determine their sub-lethal effect on the survival percentage and fecundity rate of $B$. tabaci on tomato (Lycopersicon esculentum) plants. In addition, the putative role of this partially purified B. bassiana protein in the defense mechanisms of plant was assessed through the expression analyses of important genes related to salicylic acid (SA)—and jasmonic acid (JA)—associated pathways using RT-qPCR. Results revealed a significant suppression of the survival percentage and fecundity rate of B. tabaci by the fungal protein. Lowest survival $(41 \%)$ was recorded for the highest concentration of protein $(0.063 \mu \mathrm{M})$, whereas mean survival for the other two protein concentrations $(0.042$ and $0.021 \mu \mathrm{M}$ ) were 62 and $71 \%$, respectively. Likewise, the highest and lowest mean fecundity rates were 
observed for the control and the highest protein concentration (i.e., 3.3 and 1.8 eggs day $^{-1}$ female $^{-1}$, respectively). Furthermore, the exogenous application of $B$. bassiana-derived protein on tomato plants strongly up-regulated the SA-related genes (PAL, PR1, BGL2 and EDS1) and slightly up-regulated the JA-related genes (AOC, AOS, OPR3 and LOX) as compared to the control plants. These findings demonstrate the putative role of this partially purified $B$. bassiana protein fraction in inducing systemic resistance in the tomato plants against $B$. tabaci, suggesting its further purification and characterization to be used as novel biological pest control tool against B. tabaci and other sap-sucking insect pests.

Keywords: Beauveria bassiana; Bemisia tabaci; fungal proteins; induced resistance; survival; fecundity; salicylic acid pathway; jasmonic acid pathway

\section{Introduction}

Whiteflies (Aleyrodidae: Hemiptera) are one of the most destructive sucking pests of field and horticultural crops and ornamental plants around the globe [1]. These insect pests cause substantial economic losses directly by sap-feeding of host plants and indirectly by causing different physiological disorders such as the interruption of normal plant photosynthetic activity by sooty mold growth on the host plants mediated by whitefly honeydew secretions. Furthermore, whiteflies transmit more than 114 species of plant viruses, many of which cause economically important plant diseases such as tomato yellow leaf curl virus (TYLCV), cotton leaf curl virus (CLVC), cucumber vein yellowing virus (CVYV), etc. [1-3].

The whitefly, Bemisia tabaci Genn., is one of the most invasive species worldwide. Farmers rely exclusively on the application of synthetic insecticides, particularly of organochlorines and pyrethroids, to combat $B$. tabaci infestations [4-6]. The extensive use of synthetic chemicals against whitefly populations has let to various problems such as environmental contamination, disruption of non-target fauna, pest resistance and resurgence and human health hazards. Moreover, owing to high genetic diversity, rapid population growth rates and obscure feeding behavior, whitefly populations have developed resistance against a wide range of synthetic insecticides belonging to all major chemical classes [5-9]. This situation necessitates seeking out alternate pest control methods that are environment-friendly and biorational. Microbial biopesticides, for instance, are one of the emerging and promising biological pest control strategies being developed and evaluated against many insect pest species, including B. tabaci [10-14].

Entomopathogenic fungi (EPFs) are one of the important microbial pest control agents which have been extensively studied and proven effective against a broad range of insect pests $[15,16]$. Due to their low mammalian toxicity and high host specificity, EPFs have been a core area in contemporary biological control research $[17,18]$. Apart from their direct entomopathogenicity, EPFs produce a variety of secondary metabolites which can be harmful to many insect pests [19]. For example, destruxins, efrapeptins and cordycepins, secreted respectively by Metarhizium anisopliae, Tolypocladium sp. and Cordyceps militaris, revealed the insecticidal and antifeedant effects against different lepidopterous pests $[20,21]$. Similarly, the crude proteins derived from M. anisopliae, B. bassiana and Isaria fumosorosea caused significant mortality of Musca domestica [22] and Spodoptera littoralis [23]. Recently, authored in $[24,25]$ evidenced the toxicity of filtrates and conidia extracted from different isolates of Lecanicillium lecanii and B. bassiana against M. persicae.

Moreover, some proteins synthesized by many necrotrophic and biotrophic fungi can induce resistance in plants to pathogens and herbivore pests [26-28]. Indeed, EPFs have the capability to develop endophytically within different plant tissues and induce systemic resistance in the host plants against various biotic stresses including nematodes, pathogens and phytophagous insects $[29,30]$. They have also been shown to increase the yield and growth of the plants [31,32]. This attained resistance is commonly manifested by developmental, physiological and/or biochemical responses of 
the plants under attack to any stress stimuli, for example insect herbivory, and is usually triggered through different plant defense response and signaling pathways [33].

Salicylic acid (SA) and jasmonic acid (JA) are important signaling molecules involved in the activation of plant defense pathways $[33,34]$. Although both of these plant defense pathways are triggered accumulatively in response to herbivores attack, the response of JA-associated pathway is predominantly linked to chewing herbivores [35,36], while the response of the SA-associated pathway is linked to the phloem-sucking insect pests such as aphids and whiteflies [26,37,38].

Keeping in view the above mentioned novel biological mechanisms of EPFs and their secondary proteins in the management of insect pests, this study was aimed to determine the bioactivity of a partially purified protein derived from B. bassiana (ARSEF 2860) against B. tabaci on tomato (Lycopersicon esculentum L.) plants. Furthermore, the expression levels of key genes potentially associated with JA and SA pathways were determined using RT-qPCR in order to assess the putative role of this partially purified EPF protein in induced plant resistance against $B$. tabaci.

\section{Materials and Methods}

\subsection{Plant Culture and Rearing of B. tabaci}

The seeds of tomato (L. esculentum) were soaked for 7-10 days in a sterilized Petri-plate $(100 \times 15 \mathrm{~mm})$ on a moistened filter paper disc. The healthy, vigorous and uniform tomato seedlings were transferred individually to the plastic pots $(100 \times 150 \mathrm{~mm})$ filled with a sterile mix of soil. The pots containing tomato seedlings were then kept in the growth chamber at a controlled temperature $\left(27 \pm 2{ }^{\circ} \mathrm{C}\right.$ (day) and $18 \pm 2{ }^{\circ} \mathrm{C}$ (night)) and relative humidity $(60-70 \%)$. The population of $B$. tabaci (having mixed male and female individuals) was collected from the greenhouse maintained tomato plants (CAAS, Beijing, China) and was shifted and reared on the tomato plants in laboratory at $55-65 \%$ relative humidity and $25 \pm 2{ }^{\circ} \mathrm{C}$ temperature with a $16: 8 \mathrm{~h}$ (L:D) photoperiod for about three months.

\subsection{Culture of B. bassiana}

The isolated spores of B. bassiana (ARSEF 2860), preserved in $20 \%$ glycerol at $-80^{\circ} \mathrm{C}$, were acquired from the State Key Laboratory for Biology of Plant Diseases and Insect Pests of the Institute of Plant Protection (CAAS, Beijing, China). These fungal spores were grown on potato dextrose agar (PDA) medium (potato $200 \mathrm{~g} / \mathrm{L}$, dextrose $20 \mathrm{~g} / \mathrm{L}$ and agar $20 \mathrm{~g} / \mathrm{L}$ ) in sterilized polystyrene Petri-plates $(100 \times 15 \mathrm{~mm})$ at $25 \pm 2{ }^{\circ} \mathrm{C}$ for 25 days in the dark.

\subsection{Preparation of Crude Protein and Its Partial Purification}

For this purpose, a previously described protocol [39] was followed. In brief, primary culture of B. bassiana was prepared by adding $2 \mathrm{~mL}$ of conidial suspension $\left(1.0 \times 10^{8}\right.$ conidia $\left.\mathrm{mL}^{-1}\right)$ in $100 \mathrm{~mL}$ of potato dextrose broth (PDB: dextrose $20 \mathrm{~g} / \mathrm{L}$ and potatoes $200 \mathrm{~g} / \mathrm{L}$ ) for 2 days on a rotatory shaker at $150 \mathrm{rpm}$ and $24^{\circ} \mathrm{C}$. Then, the secondary culture was prepared by the addition of $20 \mathrm{~mL}$ primary culture in $2 \mathrm{~L}$ of potato dextrose broth for 6 days on a rotatory shaker at $180 \mathrm{rpm}$ and $24^{\circ} \mathrm{C}$. Secondary culture was then centrifuged at $4{ }^{\circ} \mathrm{C}$ for $30 \mathrm{~min}$ at $12,000 \mathrm{rpm}$, and the resultant supernatant was filtered via a $0.45 \mu \mathrm{m}$ filter (Millipore Corp., Billerica, MA, USA). Partial protein purification was done using an ÄKTA Explorer 10 protein purification system (GE Healthcare, Piscataway, NJ, USA) using a HiTrap ${ }^{T M}$ HP Q 5 mL chromatography column (GE Healthcare, Uppsala, Sweden). Column equilibration was done by buffer A ( $50 \mathrm{mM}$ Tris- $\mathrm{HCl} ; \mathrm{pH} 8.0)$, and the sample of crude protein was loaded at a flow rate of $2 \mathrm{~mL} \mathrm{~min}^{-1}$. The column was washed again with buffer A. Afterwards, the buffer B $(50 \mathrm{mM}$ Tris- $\mathrm{HCl} ; 1 \mathrm{M} \mathrm{NaCl} \mathrm{pH}$ 8.0) was used to elute the proteins bounded in the column at a flowrate of $2 \mathrm{~mL} / \mathrm{min}$. A desalting column (GE Healthcare, Uppsala, Sweden) was used to desalt the eluted protein fraction. The desalted fraction of partially purified protein was analyzed using $12 \%$ sodium dodecyl sulfate polyacrylamide gel electrophoresis (SDS-PAGE). The fraction contained two proteins of 33 and $35 \mathrm{kDa}$ (Figure 1). This partially purified protein was stored at $-20^{\circ} \mathrm{C}$ until its application in 
downstream bioassays. The protein concentrations were determined using a BCA protein assay kit (Pierce, Rockford, IL, USA).

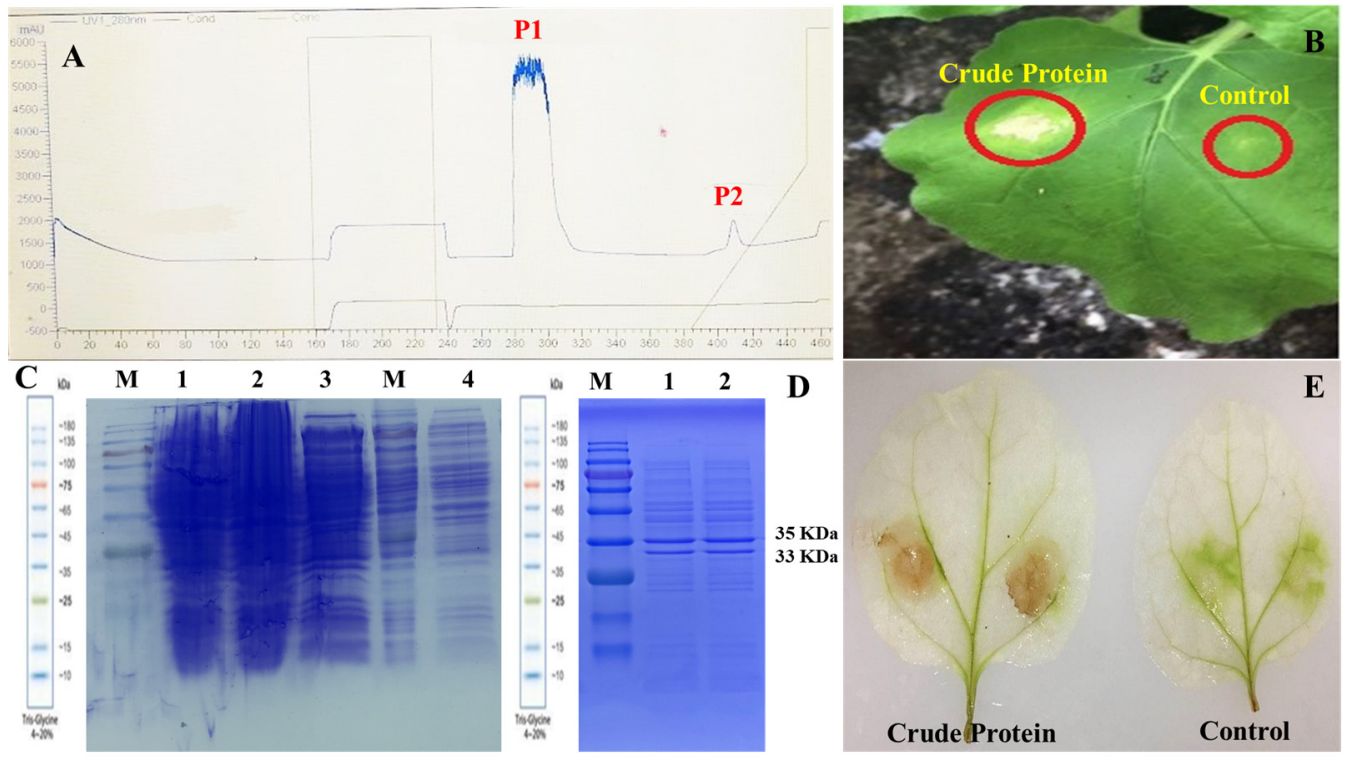

Figure 1. Crude protein purification from B. bassiana (ARSEF 2860). (A) Ion-exchange chromatography exhibited two peaks ( 1 and 2 ) of crude protein acquired from $80 \%$ ammonium sulfate precipitation and purified by the ÄKTA Explorer 10 protein purification system; (B) the necrosis induced by crude protein $(0.063 \mu \mathrm{M})$ in the leaves of $N$. tabacum observed at $24 \mathrm{~h}$ post treatment. In control treatment, the leaves of N. tabacum were treated with buffer (50 mM Tris-HCL, pH 8.0); (C) filtrate (lanes 1, 2 and 3) and proteins (lane 4) derived from B. bassiana precipitated on $12 \%$ SDS-PAGE using $80 \%$ ammonium sulfate. Lane M corresponds to molecular weight of protein markers; (D) B. bassiana-derived proteins purified through chromatography column resolved on 12\% SDS-PAGE. Lane M corresponds to molecular weight of protein markers, shown in kilodaltons. (E) ROS burst in the cells of N. tabacum observed after crude protein treatment. Brown DAB blemished precipitates represent the ROS burst.

\subsection{Bioassay of Protein Activity against B. tabaci}

The bioactivity of $B$. bassiana-derived partially purified protein was determined against $B$. tabaci whitefly in laboratory bioassays. Treatments used in these bioassays included three protein concentrations (i.e., $0.021,0.042$ and $0.063 \mu \mathrm{M}$ ) and the control. Laboratory-maintained potted tomato (L. esculentum) plants at the 5-leaf stage were used in these bioassays. Four milliliters of

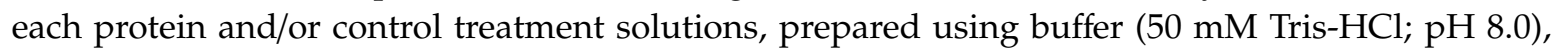
were sprayed on each plant using an aerosol spray bottle, and the sprayed plants were left to dry at room temperature $\left(25^{\circ} \mathrm{C}\right)$ for $24 \mathrm{~h}$. In order to determine the survival potential of $B$. tabaci, 10 healthy and active young whiteflies (with a 1:1 male to female ratio) were collected from laboratory-maintained B. tabaci culture and were confined on plant leaves using small leaf clip-cages (made up of transparent polystyrene rims $(25 \times 15 \mathrm{~mm})$ fitted with a fine fabric mesh on one side). Mortality of these whitefly adults was recorded daily after every $3 \mathrm{~h}$ for eight consecutive days. In order to find out the fecundity rate of $B$. tabaci, one pair of healthy and active young whitefly adults per plant was confined in leaf clip-cages. The number of eggs per female whitefly adult laid in these leaf clip-cages was noted for eight consecutive days. Ten independent replications were maintained for each treatment. All bioassays were performed at $25 \pm 2{ }^{\circ} \mathrm{C}$ and $55-65 \%$ relative humidity.

\subsection{RNA Extraction and cDNA Synthesis}

For the molecular characterization of putative plant resistance against B. tabaci induced by B. bassiana-derived protein, tomato plants were sprayed with the highest protein concentration 
(i.e., $0.063 \mu \mathrm{M}$ ), and after $24 \mathrm{~h}$, these treated plants were infested by B. tabaci adults. At $24,48,72$ and $92 \mathrm{~h}$ post-insect exposure, three leaves were randomly taken from each of the three protein-treated and/or control (buffer-treated) plants, and their total RNA was extracted using the TransGen EasyPure ${ }^{\circledR}$ plant RNA kit (TransGen Biotech, Beijing, China) following the manufacturer's protocol. Extracted RNA was quantified using a NanoPhotometer ${ }^{\circledR}$ (NP80 Touch, Implen Inc., Foster, CA, USA). Reverse transcription was then carried out to synthesize cDNA using a TransScript ${ }^{\circledR}$ One-Step gDNA Removal and cDNA Synthesis Super Mix kit (TransGen Biotech, Beijing, China).

\subsection{Real-Time Quantitative PCR (RT-qPCR)}

Relative expression of the key genes possibly involved in the defense mechanisms of L. esculentum plants was determined in whitefly-infested protein treated (with $0.063 \mu \mathrm{M}$ ) and control (buffer-treated) plants through RT-qPCR. The tested key genes were PAL, PR1, BGL2 and EDS1 of the SA pathway and AOC, AOS, OPR3 and LOX of the JA pathway. $\beta$-actin was used as an internal control (reference gene: accession no. U60481.1). Primer pairs used for the amplification of these plant defense genes are detailed in Table S1. For RT-qPCR amplifications, the thermocycler ABI 7500 Real-Time PCR System (Applied Biosystems, Foster, CA, USA) was used. The reaction mixture contained $20 \mu \mathrm{L}$ of PCR mixture $\left(10 \mu \mathrm{L} 2 \times\right.$ SYBR $^{\circledR}$ Premix Ex Taq (Takara, Dalian, China), $7 \mu \mathrm{L}$ ddH $_{2} \mathrm{O}, 2 \mu \mathrm{L}$ cDNA template and $0.5 \mu \mathrm{L}$ of reverse and $0.5 \mu \mathrm{L}$ of forward primer). The thermal protocol followed was the same as described previously [39], including a preheating at $95^{\circ} \mathrm{C}$ for $30 \mathrm{~s}$, denaturation at $95^{\circ} \mathrm{C}$ for $30 \mathrm{~s}$ (40 cycles), annealing at $60^{\circ} \mathrm{C}$ for $40 \mathrm{~s}$ and elongation at $72{ }^{\circ} \mathrm{C}$ for $60 \mathrm{~s}$. There were a total nine biological replicates (three leaves taken from each of the three independently treated tomato plants) for each treatment. The qPCR amplifications were repeated three times, and the expression levels were set at 1.0 at day 0 for each gene.

\subsection{Statistical Analysis}

Statistical analysis of the data was carried out using SPSS version 20.0.0 (SPSS Inc., Chicago, IL, USA). All experiments were repeated three times independently, and the mean values of all parameters are presented in figures along with the standard errors. The significant differences among treatments were determined using univariate general linear model of analysis of variance (ANOVA), followed by Student-Newman-Keuls (SNK) at a 0.05 level of probability. RT-qPCR expression levels of SA- and JA-associated genes were determined using the comparative $C_{\mathrm{T}}$ method. In brief, the $\Delta C_{\mathrm{T}}$ value was obtained by subtracting the $C_{\mathrm{T}}$ value of reference gene from the $C_{\mathrm{T}}$ value of target gene. The normalized fold changes of the expression of target genes were expressed as $2^{-\Delta \Delta C T}\left(=\Delta C_{T}\right.$ treated sample $-\Delta C_{T}$ control).

\section{Results}

\subsection{Crude Protein-Induced Necrosis in Tobacco Leaves}

Ion-exchange chromatography of partially purified protein extracted from B. bassiana (ARSEF 2860) exhibited two peaks (Figure 1A). These two protein peaks were collected, desalted and infiltered into the leaves of tobacco (Nicotiana tabacum cv. Samsun-NN) to find out their bioactivity. Prominent necrotic zones appeared on the treated leaf areas $24 \mathrm{~h}$ post-infiltration (Figure 1B). Afterward, SDS-PAGE gel analysis produced two distinct protein bands of molecular weight of 33 and $35 \mathrm{kDa}$ (Figure 1D). These protein bands were recovered and further bioassayed for their necrosis-inducing activity. Considerable reactive oxygen species (ROS) burst was observed in the leaves of $N$. tabacum treated with B. bassiana-derived crude protein, while no ROS burst was produced in the leaves treated with buffer (control) (Figure 1E).

\subsection{Effect of B. bassiana-Derived Protein on B. tabaci Survival}

Results of protein activity bioassays showed that the overall survival percentage of $B$. tabaci was significantly reduced on the tomato plants treated with $B$. bassiana-derived protein as compared 
to the insect survival on buffer-treated (control) plants. There was a significant effect of different concentrations of fungal protein $\left(\mathrm{F}_{3,144}=37.99 ; p \leq 0.001\right)$ and time intervals $\left(\mathrm{F}_{3,144}=5.29 ; p \leq 0.001\right)$ on the mean survival of $B$. tabaci, whereas the interaction of factors (i.e., concentrations and time) had a non-significant impact $\left(\mathrm{F}_{9,144}=0.15 ; p=0.998\right)$ (See Table 1$)$. Whitefly survival percentage was reduced along with the concentration of fungal protein. Lowest survival (41-62\%) was recorded for the highest concentration of protein $(0.063 \mu \mathrm{M})$, whereas the highest survival $(82-97 \%)$ was observed for the buffer-treated (control) plants. Mean survival of B. tabaci for the other two protein concentrations (i.e., 0.021 and $0.042 \mu \mathrm{M}$ ) were 71 and $62 \%$, respectively (cf. Figure 2).

Table 1. Univariate analysis of variance table for the effect of partially purified protein derived from B. bassiana (ARSEF 2860) on the survival percentage of B. tabaci (cf. Figure 2).

\begin{tabular}{cccccc}
\hline SOV & DF & Type III SS & MS & F-Value & $p$-Value * \\
\hline Concentration & 3 & $32,206.9$ & $10,735.6$ & 37.99 & $<0.001$ \\
Time & 3 & 4486.9 & 1496.5 & 5.29 & $<0.001$ \\
Concentration $\times$ Time & 9 & 385.6 & 42.8 & 0.15 & 0.9980 \\
Error & 144 & $40,690.0$ & 282.6 & & \\
Total & 159 & $77,769.4$ & & & \\
\hline
\end{tabular}

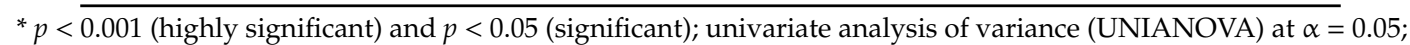
DF: degrees of freedom; SS: sum of squares; MS: mean sum of squares; F: F-statistic; CV: coefficient of variation; GM: grand mean.

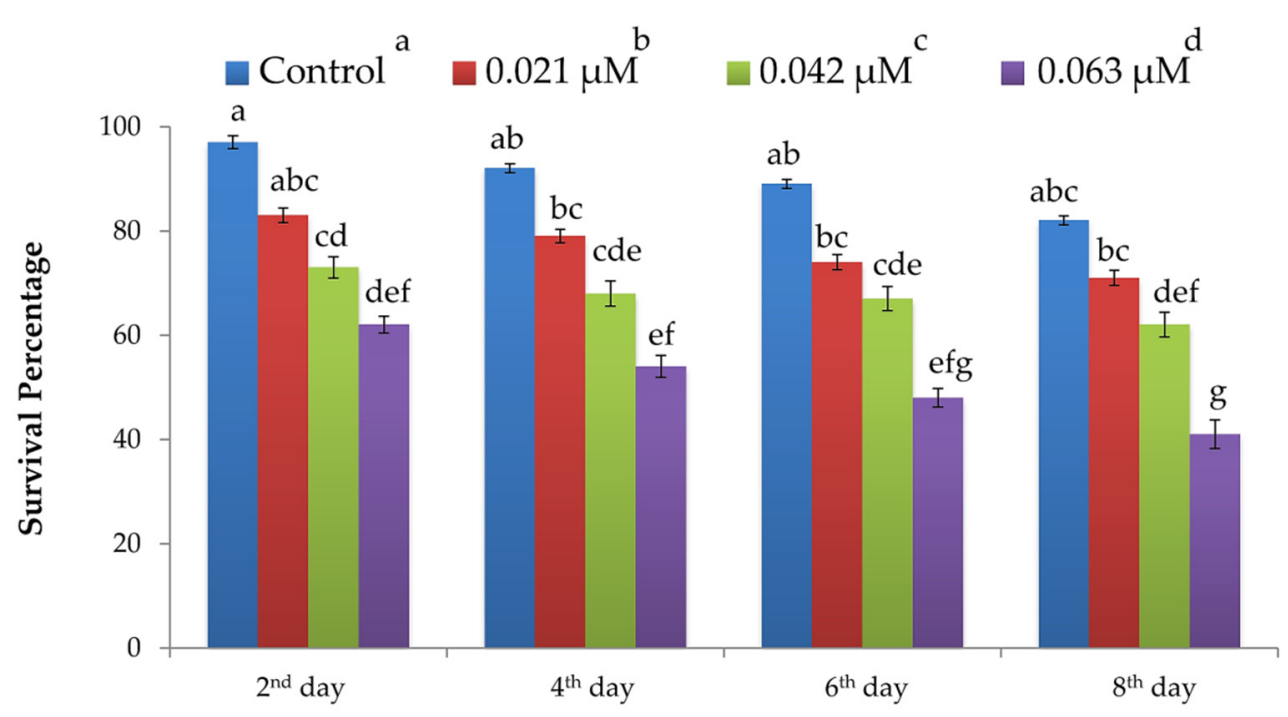

Observation Time

Figure 2. Survival percentage $( \pm \mathrm{SEM} ; n=10$ for each treatment) of whitefly (B. tabaci) recorded for different concentrations of partially purified protein derived from B. bassiana (ARSEF 2860). Different letters indicate significant difference among treatments (univariate ANOVA; SNK test at $\alpha=0.05$ ). (cf. Table 1).

\subsection{Effect of B. bassiana-Derived Protein on B. tabaci Fecundity}

Similar trend was recorded for the impact of B. bassiana-derived protein on the fecundity rate of B. tabaci. Fecundity was significantly reduced on protein-treated plants as compared to control ones. A significant effect of protein concentrations was recorded on the fecundity of $B$. tabaci $\left(\mathrm{F}_{3,288}=7.52\right.$; $p \leq 0.001$, whereas time alone and the interaction of concentration and time showed a non-significant impact (Table 2). Mean fecundity of B. tabaci was reduced along with the protein concentrations. The lowest fecundity rate $\left(1.8 \mathrm{eggs} \mathrm{day}^{-1}\right.$ female $\left.^{-1}\right)$ was observed for the highest concentration $(0.063 \mu \mathrm{M})$ of protein, while the maximum fecundity rate $\left(3.1 \mathrm{eggs} \mathrm{day}^{-1}\right.$ female $\left.^{-1}\right)$ was recorded 
for the lowest concentration $(0.021 \mu \mathrm{M})$ of protein. The mean fecundity rate observed for $0.042 \mu \mathrm{M}$ concentration of protein was 2.3 eggs day ${ }^{-1}$ female $^{-1}$. Buffer-treated (control) plants exhibited the maximum fecundity rate (3.3 eggs day ${ }^{-1}$ female $^{-1}$ ) (cf. Figure 3 ).

Table 2. Univariate analysis of variance table for the effect of partially purified protein purified of Beauveria bassiana (ARSEF 2860) on the fecundity rate of B. tabaci (cf. Figure 3).

\begin{tabular}{cccccc}
\hline SOV & DF & Type III SS & MS & F-Value & $p$-Value * \\
\hline Concentration & 3 & 59.261 & 19.7538 & 7.52 & $<0.001$ \\
Time & 7 & 14.162 & 2.0231 & 0.77 & 0.6130 \\
Concentration $\times$ Time & 21 & 2.882 & 0.1373 & 0.05 & 1.0000 \\
Error & 288 & 776.115 & 2.6278 & & \\
Total & 391 & 850.966 & & & \\
GM/CV & & $3.02 / 53.75$ & & & \\
\hline
\end{tabular}

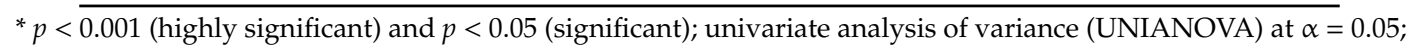
DF: degrees of freedom; SS: sum of squares; MS: mean sum of squares; F: F-statistic; CV: coefficient of variation; GM: grand mean.

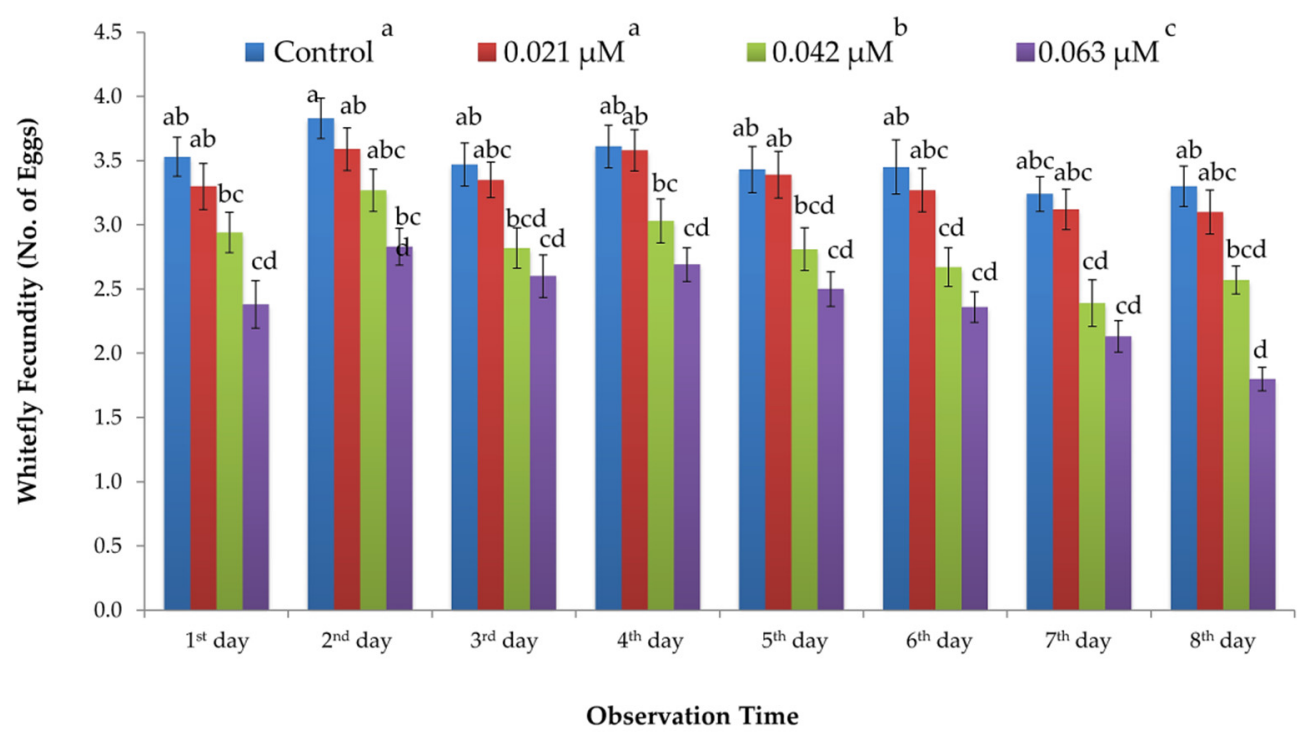

Figure 3. Fecundity rate ( $\pm \mathrm{SEM} ; n=5$ for each treatment) of whitefly (B. tabaci) recorded for different concentrations of partially purified protein derived from B. bassiana (ARSEF 2860). Different letters indicate significant difference among treatments (univariate ANOVA; SNK test at $\alpha=0.05$ ). (cf. Table 2).

\subsection{Expression Levels of Plant Defense Related Genes in Response to B. basiana-Derived Protein}

In order to find out the putative role of $B$. bassiana-derived protein in induced resistance in L. esculentum plants against $B$. tabaci, the expression of key genes related to JA- and SA-associated plant defense pathways were analyzed by RT-qPCR. Results revealed a significant $(p=0.05)$ up-regulation of all SA-associated pathway genes (PAL, PR1, BGL2 and EDS1; Table S1) observed at all post-insect exposure time intervals (Figure 4), whereas JA-associated pathway genes (AOC, AOS, OPR3 and LOX; Table S1) were moderately or slightly up-regulated (Figure 5). The maximum expressions of all the tested genes were recorded at $72 \mathrm{~h}$ post-insect exposure, as evidenced by a heat map of the gene expressions (Figure 6). 


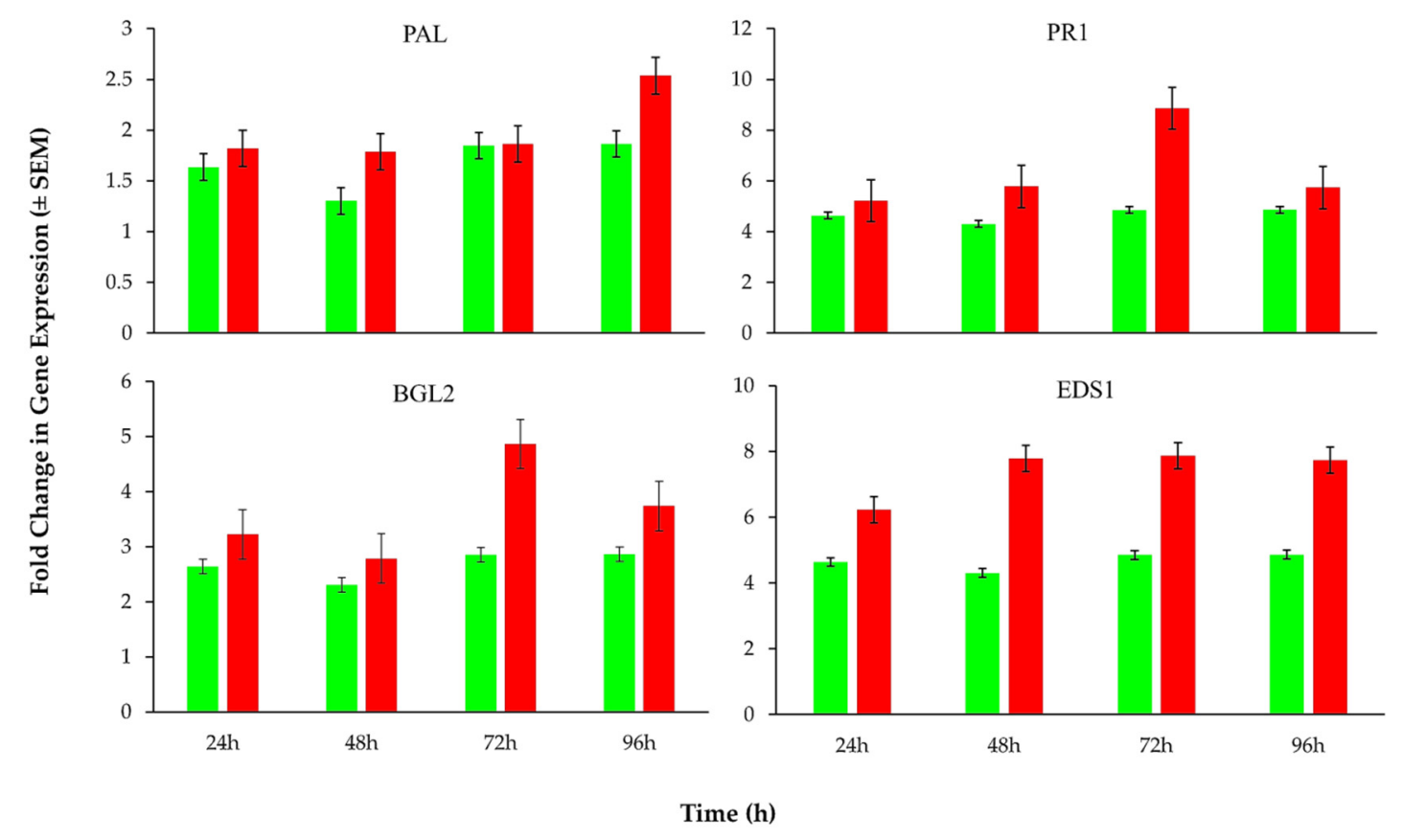

Figure 4. Expression levels of key genes potentially linked to the salicylic acid (SA)-associated plant defense pathways determined at different post-treatment time intervals (sample size $n=9$ for each treatment). Green and red columns represent the results for buffer-treated (control) and protein-treated plants, respectively.
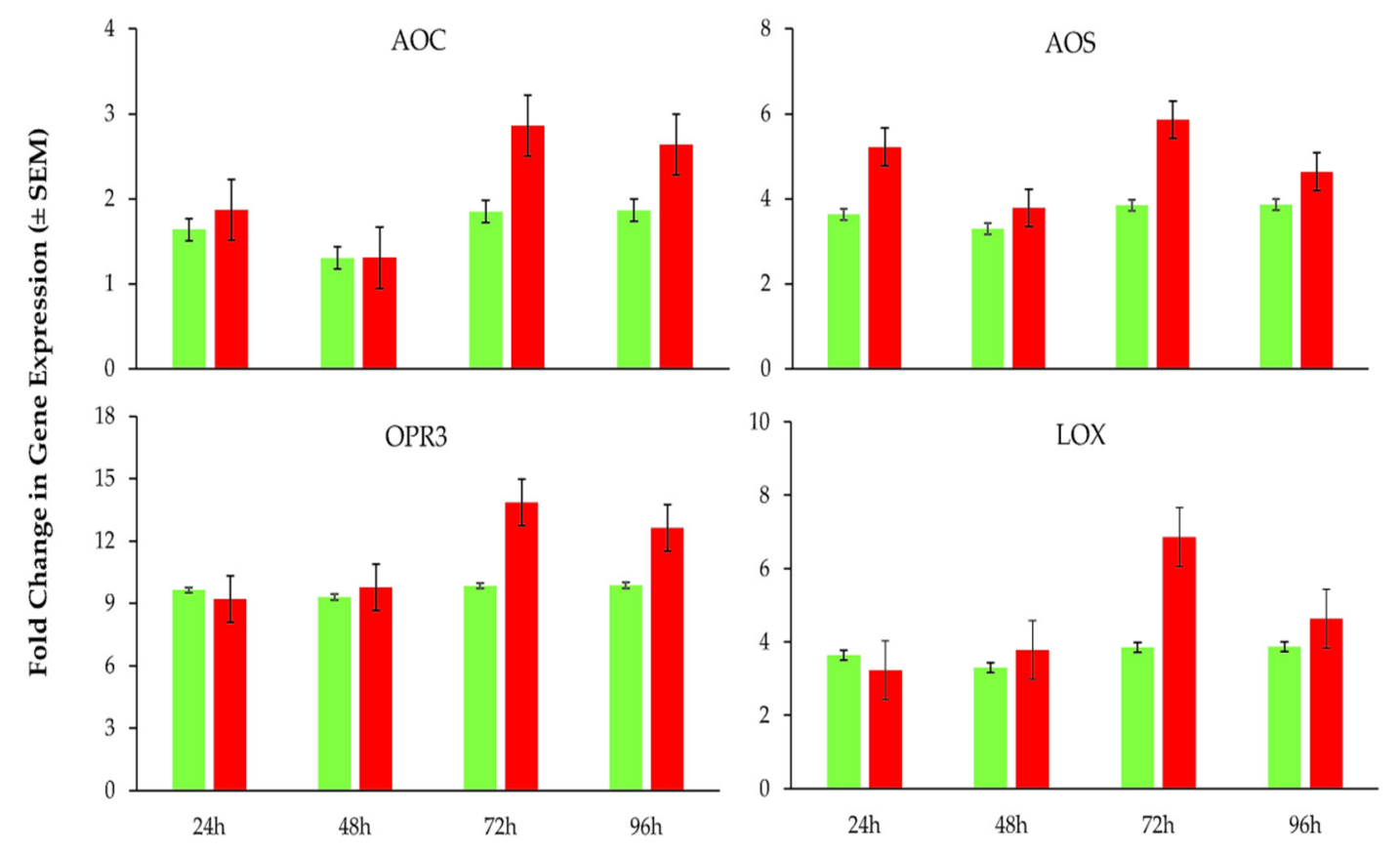

Time (h)

Figure 5. Expression levels of key genes potentially linked to the jasmonic acid (JA)-associated plant defense pathways determined at different post-treatment time intervals (sample size $n=9$ for each treatment). Green and red columns represent the results for buffer-treated (control) and protein-treated plants, respectively. 


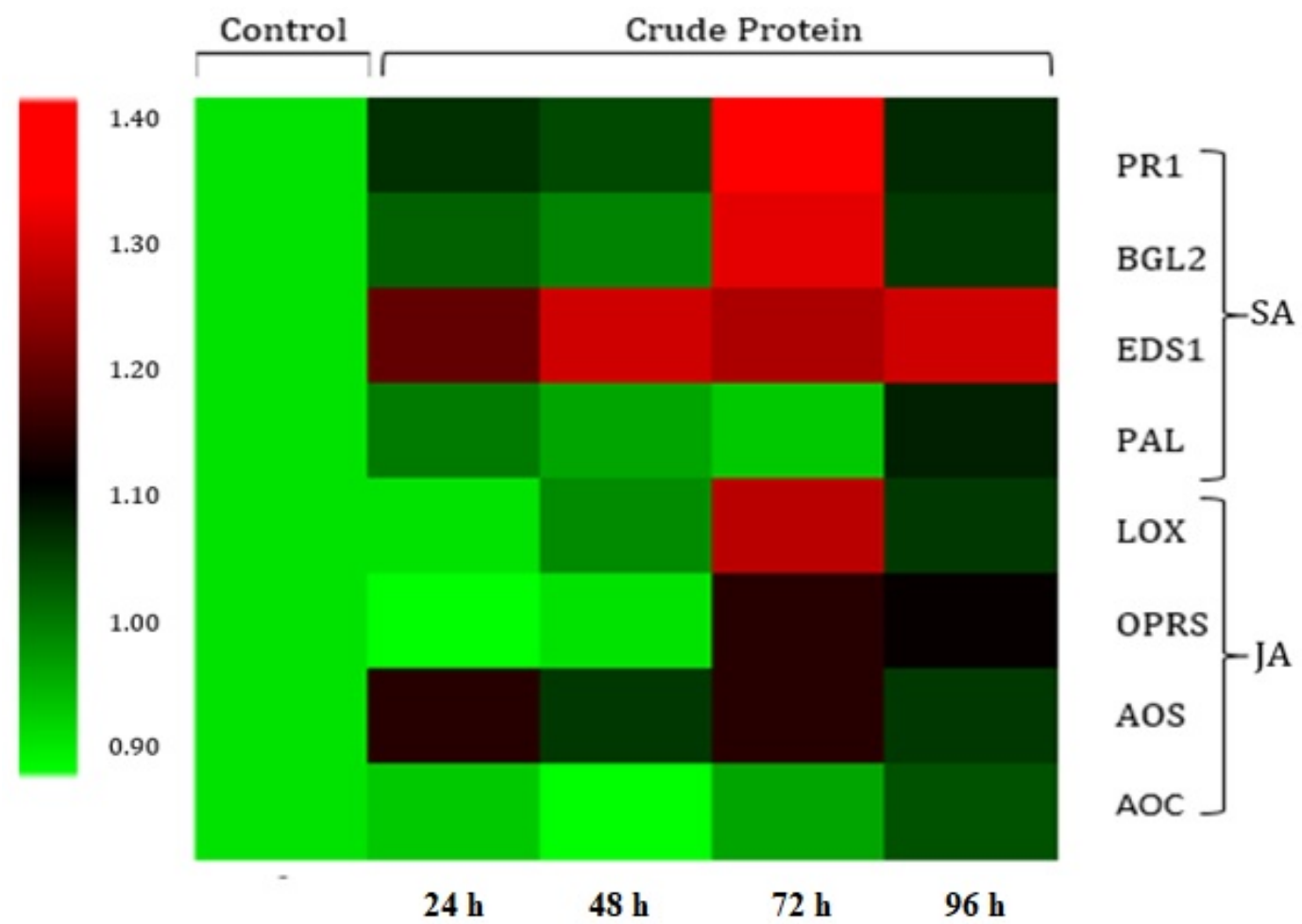

Figure 6. Heat map for genes expression linked to the JA- and SA-associated plant defense pathways showing the relative expression levels at $24,48,72$ and $96 \mathrm{~h}$ post-insect exposure. Scale color bar in the picture shows low (green) to high (red) gene expression. The heat map was generated using Multi Experiment Viewer (MeV, version 4.6.0) software.

\section{Discussion}

Plants rely on an array of defense mechanisms regarding their response to various biotic stresses, for example insect herbivory [40,41]. These defense mechanisms are usually activated by different types of signaling molecules such as SA and JA, and through several microbe-induced and herbivore-induced elicitor molecules [34]. These elicitors are often glycoproteins, proteins and lipids, which trigger resistance in the plants against different pathogens and herbivores [42-44]. Similarly, some strains of EPFs synthesize certain protein molecules in addition to their direct entomotoxicity, which can induce plant resistance against different pathogens and herbivore insects [27].

This laboratory study evaluated the bioactivity of a partially purified protein derived from EPF B. bassiana (ARSEF 2860) against whitefly B. tabaci on tomato (L. esculentum) plants. Plants treated with the exogenous application of $B$. bassiana protein manifested a significant suppression of the survival and fecundity of $B$. tabaci as compared to the control plants. These findings are in accordance with [45], which showed a significant reduction in the fecundity of Aphis gossypii by the exogenous applications of fungal filtrates and conidial of endophytic fungi B. bassiana and L. lecanii. Likewise, our findings corroborate the results of [22] demonstrating a considerable negative impact of the crude protein derived from B. bassiana, I. fumosorosea and M. anisopliae on the survival percentage of M. domestica. Our results are in accordance as well with authors in [39], who revealed that feeding on plants of L. esculentum treated by L. lecanii-derived partially purified protein significantly affected the fecundity rate and survival percentage of M. persicae. Similarly, some previous studies have revealed the significant sub-lethal and toxic effects of crude proteins extracted from different isolates of M. anisopliae and B. bassiana on Dysdercus cingulatus [46] and S. litturalis [23]. Moreover, some previous works proved that the exogenous application of such proteins related to plant defense as jasmonates and methyl salicylate might disrupt the activity of chewing [47] and sucking [48,49] insect pests on tomato plants. 
Gene expression analyses showed that the exogenous application of B. bassiana-derived protein strongly up-regulated the SA-associated pathway genes, while those related to JA-associated pathway were partially up-regulated. These results validate the fact that herbivory by sap-sucking insects, for instance whiteflies, is more often manifested with enhanced expression levels of SA pathway-related genes $[34,38]$. Our results are in line with a recent study [50] that revealed important sub-lethal effects of the B. bassiana-derived PeBb1 protein elicitor on M. persicae on the plants of Brassica rapa concomitantly with the enhanced expression of JA and Et pathway-related genes.

The results of this study elucidate the potential eliciting role of $B$. bassiana-derived protein in suppressing B. tabaci fecundity rate and survival percentage on the plants of tomato. However, as different plant elicitor molecules, such as SA and JA, may activate the inhibition of proteinase in tomato plants [47,51], additional studies are required to better understand how this B. bassiana-derived protein influences the plant systems and insect fitness parameters. Moreover, although this fungal protein showed significant suppression of $B$. tabaci life traits under laboratory conditions, however, keeping in view the high biotic potential and population growth rate of $B$. tabaci, further studies are needed to enhance the anti-insect effect of this protein, so that it can be used successfully as an important biological pest management tool under field conditions.

\section{Conclusions}

In brief, this laboratory study demonstrated that feeding on L. esculentum plants treated with B. bassiana-derived partially purified protein significantly reduced the fecundity rate and survival percentage of B. tabaci. Furthermore, the expression level of key genes associated with plant defense signaling pathways were highly up-regulated in the plants receiving the exogenous application of B. bassiana-derived protein, recommending its putative efficiency as novel biocontrol tool against B. tabaci and other sap-feeding herbivores. However, further studies are needed regarding the purification and functional and molecular characterizations of this partially purified B. bassiana protein.

Supplementary Materials: The following are available online at http://www.mdpi.com/2075-4450/11/9/574/s1, Table S1: Primer pairs used in this study for RT-qPCR amplifications of the key genes potentially involved in the plant defense (SA and JA) pathways.

Author Contributions: Conceptualization, A.U.K. and T.N.; Data curation, A.U.K., Y.A.A., T.N. and D.Q.; Formal analysis, M.Z.M., A.U.K., T.N. and T.A.; Funding acquisition, D.Q.; Investigation, A.U.K., Y.A.A. and T.N.; Methodology, A.U.K., G.H.J. and M.A.G.; Project administration, D.Q.; Resources, D.Q.; Software, A.U.K. and T.N.; Supervision, D.Q.; Visualization, T.N.; Writing—original draft, A.U.K., T.A. and G.H.J.; Writing-review and editing, M.Z.M., T.N. and D.Q. All authors have read and agreed to the published version of the manuscript.

Funding: This research work was financially aided by the Graduate School of the Chinese Academy of Agricultural Sciences (GSCAAS) and by the National Key Research and Development Program of China (2017YFD0200900).

Acknowledgments: The authors thank Lihua Guo and Xiufen Yang of the Institute of Plant Protection (CAAS, Beijing, China) and Rezwan Tariq of the Institute of Crop Sciences (CAAS, Beijing, China) for their valuable advice on the experimental protocols and for their technical assistance.

Conflicts of Interest: The authors declare no conflict of interest.

\section{References}

1. De Barro, P.J.; Liu, S.-S.; Boykin, L.M.; Dinsdale, A.B. Bemisia tabaci: A statement of species status. Annu. Rev. Entomol. 2011, 56, 1-19. [CrossRef] [PubMed]

2. Fortes, I.M.; Sánchez-Campos, S.; Fiallo-Olivé, E.; Díaz-Pendón, J.A.; Navas-Castillo, J.; Moriones, E. A novel strain of tomato leaf curl New Delhi virus has spread to the Mediterranean basin. Viruses 2016, 8, 307. [CrossRef] [PubMed]

3. Abrahamian, P.; Sobh, H.; Seblani, R.; Abou-Jawdah, Y. Co-infection of two criniviruses and a begomovirus enhances the disease severity in cucumber. Eur. J. Plant Pathol. 2015, 142, 521-530. [CrossRef]

4. Qiu, B.L.; Ren, S.X.; Sun, T.X.; Lin, L.; Kuang, Z.B. Preliminary report on the host plants of Bemisia tabaci in Guangzhou. J. South China Agric. Univ. 2001, 22, 43-47. 
5. Cahill, M.; Denholm, I.; Ross, G.; Gorman, K.; Johnston, D. Relationship between bioassay data and the simulated field performance of insecticides against susceptible and resistant adult Bemisia tabaci (Homoptera: Aleyrodidae). Bull. Entomol. Res. 1996, 86, 109-116. [CrossRef]

6. Cuthbertson, A.G.S.; Blackburn, L.F.; Eyre, D.P.; Cannon, R.J.C.; Miller, J.; Northing, P. Bemisia tabaci: The current situation in the UK and the prospect of developing strategies for eradication using entomopathogens. Insect Sci. 2011, 18, 1-10. [CrossRef]

7. Horowitz, A.R.; Kontsedalov, S.; Ishaaya, I. Dynamics of resistance to the neonicotinoids acetamiprid and thiamethoxam in Bemisia tabaci (Homoptera: Aleyrodidae). J. Econ. Entomol. 2004, 97, 2051-2056. [CrossRef]

8. Silva, L.D.; Omoto, C.; Bleicher, E.; Dourado, P.M. Monitoring the susceptibility to insecticides in Bemisia tabaci (Gennadius) (Hemiptera: Aleyrodidae) populations from Brazil. Neotrop. Entomol. 2009, 38, 862-871. [CrossRef]

9. Horowitz, A.R.; Kontsedalov, S.; Khasdan, V.; Ishaaya, I. Biotypes B and Q of Bemisia tabaci and their relevance to neonicotinoid and pyriproxyfen resistance. Arch. Insect Biochem. Physiol. Publ. Collab. Entomol. Soc. Am. 2005, 58, 216-225.

10. Goolsby, J.A.; Ciomperlik, M.A.; Legaspi, B.C.; Legaspi, J.C.; Wendel, L.E. Laboratory and field evaluation of exotic parasitoids of Bemisia tabaci (Biotype 'B') in the Lower Rio Grande Valley of Texas. In Biological Control; Citeseer: State College, PA, USA, 1998; pp. 127-135.

11. Wan, F.-H.; Yang, N.-W. Invasion and management of agricultural alien insects in China. Annu. Rev. Entomol. 2016, 61, 77-98. [CrossRef]

12. Lacey, L.A.; Frutos, R.; Kaya, H.K.; Vail, P. Insect pathogens as biological control agents: Do they have a future? Biol. Control 2001, 21, 230-248. [CrossRef]

13. Naranjo, S.E.; Ellsworth, P.C.; Frisvold, G.B. Economic value of biological control in integrated pest management of managed plant systems. Annu. Rev. Entomol. 2015, 60, 621-645. [CrossRef] [PubMed]

14. Kumar, K.K.; Sridhar, J.; Murali-Baskaran, R.K.; Senthil-Nathan, S.; Kaushal, P.; Dara, S.K.; Arthurs, S. Microbial biopesticides for insect pest management in India: Current status and future prospects. J. Invertebr. Pathol. 2019, 165, 74-81. [CrossRef] [PubMed]

15. Cabanillas, H.E.; Jones, W.A. Pathogenicity of Isaria sp. (Hypocreales: Clavicipitaceae) against the sweet potato whitefly B biotype, Bemisia tabaci (Hemiptera: Aleyrodidae). Crop Prot. 2009, 28, 333-337. [CrossRef]

16. Majeed, M.Z.; Fiaz, M.; Ma, C.-S.; Afzal, M. Entomopathogenicity of three muscardine fungi, Beauveria bassiana, Isaria fumosorosea and Metarhizium anisopliae, against the Asian citrus psyllid, Diaphorina citri Kuwayama (Hemiptera: Psyllidae). Egypt. J. Biol. Pest Control 2017, 27, 211-215.

17. Vega, F.E.; Goettel, M.S.; Blackwell, M.; Chandler, D.; Jackson, M.A.; Keller, S.; Koike, M.; Maniania, N.K.; Monzon, A.; Ownley, B.H. Fungal entomopathogens: New insights on their ecology. Fungal Ecol. 2009, 2, 149-159. [CrossRef]

18. Wraight, S.P.; Carruthers, R.I. Production, delivery, and use of mycoinsecticides for control of insect pests on field crops. In Biopesticides: Use and Delivery; Springer: New York, NY, USA, 1999; pp. 233-269.

19. Vey, A.; Hoagland, R.E.; Butt, T.M. 12 Toxic Metabolites of Fungal Biocontrol Agents. Fungi as Biocontrol Agents; Springer: New York, NY, USA, 2001; p. 311.

20. Bandani, A.R.; Khambay, B.P.S.; Faull, J.L.; Newton, R.; Deadman, M.; Butt, T.M. Production of efrapeptins by Tolypocladium species and evaluation of their insecticidal and antimicrobial properties. Mycol. Res. 2000, 104, 537-544. [CrossRef]

21. Kim, J.; Yeon, S.; Kim, H.; Ahn, Y. Larvicidal activity against Plutella xylostella of cordycepin from the fruiting body of Cordyceps militaris. Pest Manag. Sci. Former. Pestic. Sci. 2002, 58, 713-717. [CrossRef]

22. Farooq, M.; Freed, S. Insecticidal activity of toxic crude proteins secreted by entomopathogenic fungi against Musca domestica L. (Diptera: Muscidae). Kuwait J. Sci. 2018, 45, 64-74.

23. Quesada-Moraga, E.; Carrasco-Díaz, J.; Santiago-Álvarez, C. Insecticidal and antifeedant activities of proteins secreted by entomopathogenic fungi against Spodoptera littoralis (Lep., Noctuidae). J. Appl. Entomol. 2006, 130, 442-452. [CrossRef]

24. Nazir, T.; Basit, A.; Hanan, A.; Majeed, M.; Qiu, D. In vitro pathogenicity of some entomopathogenic fungal strains against green peach aphid Myzus persicae (Homoptera: Aphididae). Agronomy 2019, 9, 7. [CrossRef]

25. Hanan, A.; Nazir, T.; Basit, A.; Ahmad, S.; Qiu, D. Potential of Lecanicillium lecanii (Zimm.) as a microbial control agent for green peach aphid, Myzus persicae (Sulzer)(Hemiptera: Aphididae). Pak. J. Zool. 2020, 52, 131. [CrossRef] 
26. Basit, A.; Hanan, A.; Nazir, T.; Majeed, M.Z.; Qiu, D. Molecular and functional characterization of elicitor PeBC1 extracted from Botrytis cinerea involved in the induction of resistance against green peach aphid (Myzus persicae) in common beans (Phaseolus vulgaris L.). Insects 2019, 10, 35. [CrossRef] [PubMed]

27. Maffei, M.E.; Arimura, G.-I.; Mithöfer, A. Natural elicitors, effectors and modulators of plant responses. Nat. Prod. Rep. 2012, 29, 1288-1303. [CrossRef] [PubMed]

28. Kliebenstein, D.J.; Rowe, H.C. Ecological costs of biotrophic versus necrotrophic pathogen resistance, the hypersensitive response and signal transduction. Plant Sci. 2008, 174, 551-556. [CrossRef]

29. Jaber, L.R.; Ownley, B.H. Can we use entomopathogenic fungi as endophytes for dual biological control of insect pests and plant pathogens? Biol. Control 2018, 116, 36-45. [CrossRef]

30. Sánchez-Rodríguez, A.R.; Raya-Díaz, S.; Zamarreño, Á.M.; García-Mina, J.M.; del Campillo, M.C.; Quesada-Moraga, E. An endophytic Beauveria bassiana strain increases spike production in bread and durum wheat plants and effectively controls cotton leafworm (Spodoptera littoralis) larvae. Biol. Control 2018, 116, 90-102. [CrossRef]

31. Behie, S.W.; Zelisko, P.M.; Bidochka, M.J. Endophytic insect-parasitic fungi translocate nitrogen directly from insects to plants. Science 2012, 336, 1576-1577. [CrossRef]

32. Kabaluk, J.T.; Ericsson, J.D. Metarhizium anisopliae seed treatment increases yield of field corn when applied for wireworm control. Agron. J. 2007, 99, 1377-1381. [CrossRef]

33. Puthoff, D.P.; Holzer, F.M.; Perring, T.M.; Walling, L.L. Tomato pathogenesis-related protein genes are expressed in response to Trialeurodes vaporariorum and Bemisia tabaci biotype B feeding. J. Chem. Ecol. 2010, 36, 1271-1285. [CrossRef]

34. Thaler, J.S.; Agrawal, A.A.; Halitschke, R. Salicylate-mediated interactions between pathogens and herbivores. Ecology 2010, 91, 1075-1082. [CrossRef] [PubMed]

35. Diezel, C.; von Dahl, C.C.; Gaquerel, E.; Baldwin, I.T. Different lepidopteran elicitors account for cross-talk in herbivory-induced phytohormone signaling. Plant Physiol. 2009, 150, 1576-1586. [CrossRef] [PubMed]

36. Wu, J.; Baldwin, I.T. Herbivory-induced signalling in plants: Perception and action. Plant. Cell Environ. 2009, 32, 1161-1174. [CrossRef] [PubMed]

37. Moran, P.J.; Cheng, Y.; Cassell, J.L.; Thompson, G.A. Gene expression profiling of Arabidopsis thaliana in compatible plant-aphid interactions. Arch. Insect Biochem. Physiol. Publ. Collab. Entomol. Soc. Am. 2002, 51, 182-203. [CrossRef] [PubMed]

38. Zhang, T.; Luan, J.; Qi, J.; Huang, C.; Li, M.; Zhou, X.; Liu, S. Begomovirus-whitefly mutualism is achieved through repression of plant defences by a virus pathogenicity factor. Mol. Ecol. 2012, 21, 1294-1304. [CrossRef]

39. Hanan, A.; Basit, A.; Nazir, T.; Majeed, M.Z.; Qiu, D. Anti-insect activity of a partially purified protein derived from the entomopathogenic fungus Lecanicillium lecanii (Zimmermann) and its putative role in a tomato defense mechanism against green peach aphid. J. Invertebr. Pathol. 2020, 170, 107282. [CrossRef]

40. Glazebrook, J. Contrasting mechanisms of defense against biotrophic and necrotrophic pathogens. Annu. Rev. Phytopathol. 2005, 43, 205-227. [CrossRef]

41. Walling, L.L. Adaptive defense responses to pathogens and insects. Adv. Bot. Res. 2009, 51, 551-612.

42. Chen, M.; Zhang, C.; Zi, Q.; Qiu, D.; Liu, W.; Zeng, H. A novel elicitor identified from Magnaporthe oryzae triggers defense responses in tobacco and rice. Plant Cell Rep. 2014, 33, 1865-1879. [CrossRef]

43. Dodds, P.N.; Rathjen, J.P. Plant immunity: Towards an integrated view of plant-pathogen interactions. Nat. Rev. Genet. 2010, 11, 539-548. [CrossRef]

44. Garcia-Brugger, A.; Lamotte, O.; Vandelle, E.; Bourque, S.; Lecourieux, D.; Poinssot, B.; Wendehenne, D.; Pugin, A. Early signaling events induced by elicitors of plant defenses. Mol. Plant-Microbe Interact. 2006, 19, 711-724. [CrossRef] [PubMed]

45. Gurulingappa, P.; McGee, P.A.; Sword, G. Endophytic Lecanicillium lecanii and Beauveria bassiana reduce the survival and fecundity of Aphis gossypii following contact with conidia and secondary metabolites. Crop Prot. 2011, 30, 349-353. [CrossRef]

46. Sahayaraj, K.; Tomson, M. Impact of two pathogenic fungal crude metabolites on mortality, biology and enzymes of Dysdercus cingulatus (Fab.) (Hemiptera: Pyrrhocoridae). J. Biopestic. 2010, 3, 163-167.

47. Thaler, J.S.; Stout, M.J.; Karban, R.; Duffey, S.S. Exogenous jasmonates simulate insect wounding in tomato plants (Lycopersicon esculentum) in the laboratory and field. J. Chem. Ecol. 1996, 22, 1767-1781. [CrossRef] [PubMed] 
48. Boughton, A.J.; Hoover, K.; Felton, G.W. Impact of chemical elicitor applications on greenhouse tomato plants and population growth of the green peach aphid, Myzus persicae. Entomol. Exp. Appl. 2006, 120, 175-188. [CrossRef]

49. Mallinger, R.E.; Hogg, D.B.; Gratton, C. Methyl salicylate attracts natural enemies and reduces populations of soybean aphids (Hemiptera: Aphididae) in soybean agroecosystems. J. Econ. Entomol. 2011, 104, 115-124. [CrossRef]

50. Nazir, T.; Hanan, A.; Basit, A.; Majeed, M.Z.; Anwar, T.; Nawaz, I.; Qiu, D. Putative role of a yet uncharacterized protein elicitor PeBb1 derived from Beauveria bassiana ARSEF 2860 strain against Myzus persicae (Homoptera: Aphididae) in Brassica rapa ssp. pekinensis. Pathogens 2020, 9, 111. [CrossRef]

51. Farmer, E.E.; Johnson, R.R.; Ryan, C.A. Regulation of expression of proteinase inhibitor genes by methyl jasmonate and jasmonic acid. Plant Physiol. 1992, 98, 995-1002. [CrossRef]

(C) 2020 by the authors. Licensee MDPI, Basel, Switzerland. This article is an open access article distributed under the terms and conditions of the Creative Commons Attribution (CC BY) license (http://creativecommons.org/licenses/by/4.0/). 